\title{
LUCIE ČESÁLKOVÁ
}

\section{Filmmakers to Themselves? Czech Documentary Cinema After 2000}

In 2002, the Czech daily Právo published an interview with four documentary filmmakers, Jan Gogola, Vít Janeček, Martin Mareček and Filip Remunda, aptly named after the key theme "Otherness in Today's Czech Documentary Film”. Through the term "other film”, introduced into the debate by Jan Gogola, the authors distanced themselves from work that relies on established standards, and in this sense, produces types of products attributable to pre-defined and proven genre categories, such as action film, comedy, etc. In what was then de facto an avant-garde fashion, Gogola called for an art that would always be new, always unexpected, always transcending existing conventions. "Other film", he said, "should be unpredictable, other than the previous one, it should be a genre of its kind under which it is not only about shooting, but also about 'being shot."' [1] In their attitudes, the above-mentioned filmmakers reveal the influence of their teacher, filmmaker Karel Vachek, who made subversion and provocation the core of his artistic program, a method for a complex re-thinking of Czech society, politics, culture, and the arts.[2] The debate about otherness in the documentary, however, is significant for reasons other than genealogical ones. In a broader sense, "otherness" is merely one shard of a distinct and almost pathological tendency in Czech documentary filmmaking to "differentiate itself".

Challenging the old state of affairs was the distinct subtext of the program statement for the Burza námětů (Pitching Forum) initiative, realized for the first time in 2001, out of which the Institute of Documentary Film developed. What is perhaps most striking, however, is the discourse of otherness surrounding Czech documentary film promoted by the Jihlava International Documentary Film Festival. The festival, established in 1997, models itself in its various program statements as a creative art workshop with almost elite foundations:

The Jihlava International Documentary Film Festival is a celebration of creative documentary film and the greatest event of its kind in Central and Eastern Europe. We conceive of documentary films primarily as unique artworks dealing with significant themes. To us, the festival represents an artifact, an inspiring and playful reflection of the world from various perspectives. We do not follow common festival models, nor do we have

[1] M. Procházka, M. Švoma, "Jinakost v českém dokumentárním filmu”, Právo 2002, 31, October.
Images

vol. XV/no. 24

Poznań 2014

ISSN 1731-45OX 
a routine, pragmatic approach to program selection. Jihlava pays tribute to courage and risk. [3]

In the rhetoric of self-presentation, the Jihlava festival emphasizes the artistry of the event, promoting the festival itself as an artifact. The festival here admits, maintains and celebrates its ritual character, explicitly dissociates itself from the common practices of the festival dramaturgy, professes the values of "artistry", "creativity", "provocativeness", and, the value of "authorship" in its Czech version, calling for creativity in documentary film through the Czech autorský dokument (auteur documentary). By means of this cinephilia-tuned attitude, it situates itself in the position of an elite culture.

The need to demonstrate otherness is usually associated with subcultures understood in a wider (not pejorative, but genuinely productive) sense within the culture of "shared ideas", whose interactions can take place both in a real context (in this example, shows, festivals, and other, generally club-related events) and in a virtual environment. However, the important thing is that the essence of a subculture is its (at least partial) integrity, consisting, as already mentioned, of idea sharing, or more generally, of a universal code.[4] Demonstrating otherness in relation to an outside world is thus necessarily accompanied by a confirmation of internal unity. How the validation of this exclusivity, which rests, as we will discuss in more detail, on rather vague foundations, significantly shapes and distorts the space of contemporary Czech documentary film will thus constitute the main leitmotiv of this text.

The specificity of the Czech documentary of the last decade can be attributed to the extent to which all of its spheres are personally interlinked - not only in terms of networks of friendship, but also in the accumulation of functions within them. The same people are teachers of documentary film at the Film and TV School of the Academy of Performing Arts, translators and commentators of important studies of documentary filmmaking, occasional journalists and magazine publishers on the documentary, and television programmers and festivals organizers; they contribute to the functioning of support institutions and evaluate grant applications, and also make films. Solidarity and closeness, community, and an elite nature, all characteristics related to these spheres of operation, can have a number of positive and negative social connotations and implications. Evaluating issues like this, however, is not the task of this study. However, dismantling the implications and contradictions of a crystallizing elite documentary film community will be crucial on several levels here, both in terms of marking the field and the borders between production and co-production, as well as in terms of film style. In the first part of this study, therefore, I will focus on the concept of "creative/auteur cinema" as a discursive construct

[3] See the statement "About festival", which is repeated on other festivals' promotional materials, online: <http://www.dokument-festival.cz/about-us> [accessed: February 24th, 2014].
[4] For more about subcultures see Ch. Jenks, Subculture: the Fragmentation of the Social, Sage Publications, London 2005, R. Hebdige, Subculture: The Meaning of Style, Routledge, New York 1979. 
established by the Jihlava festival, and then discuss the problematic relationship of Czech documentary filmmakers and Czech Television (CT) as a "good and evil" partner.

The Jihlava International Documentary Film Festival has called itself the "celebration of creative documentary film", and in doing so it has both highlighted the ritual nature of festival events through the metaphor of celebration, and has made "creative documentaries" an object of celebration. Alongside this manifesto, the discursive fetishization of the term "creative documentary" (festival's translation of Czech autorský dokument /auteur documentary/)has further been developed both in texts in the journal Dok. revue, published by festival organizers (Spolek amatérských filmařu Jihlava/The Society of Amateur Filmmakers Jihlava), and in interviews with the filmmakers whose films the festival has exhibited. Although it has never been conceptually described or defined, "creative documentary" has become a label that can be used to describe "otherness", though in itself it remains empty.

Conceived as a category defining the festival's focus, "creative documentary" basically stands for a dramaturgical category, helping the organizers of the festival to distinguish what does and does not fit into their concept. In this sense, the category is legitimate even in its vagueness - it is an intrinsic norm that co-creates the program policy of the festival, which does not need to be specified externally. When, however, the internal standard is revealed to the public and, moreover, clearly used as a value for "better" filmmaking, its vagueness becomes problematic. "Creative documentary" entered the realm of broader awareness through the publishing activities of the festival. From 2003 to 2005, the festival published six volumes of theoretical texts in a collection called $D O$, and since 2005 it has published Dok.revue, which up until 2007 was issued as a monthly supplement to the weekly Literární noviny.[5] On its four newspaper pages Dok.revue contains essays, texts and thematic reviews. Marek Hovorka, Petr Kubica, Andrea Slováková and Vít Janeček (all teachers at FAMU; Slováková and Janeček are also filmmakers) constitute the editorial board. Since 2008, Dok.revue has been published five times a year as a color five-page supplement to the weekly Respekt, with similar editorial auspices. In addition to this publication platform, however, the phrase "creative documentary" has also penetrated the vocabulary of filmmakers themselves, and they, paradoxically, have self-identified with this category, and become its most frequent interpreters.

They have most often done so in interviews when challenged by journalists, when giving individual, subjective interpretations, and hence the meaning of the concept has not been narrowed, but rather, just the opposite. In the previously-mentioned interview, where otherness was described as the method of Gogola, Mareček, Janeček and Remunda, there also appeared reflections on "other film" as "creative documentary"

[5] See: <http://www.dokrevue.cz/en/about-dok-re-

vue $>$ [accessed: February 24th, 2014].

The creative documentary party and its guests 
in the sense of the "author's main responsibility, and therefore 'authority', regarding the theme and employed means." From other newspaper statements where filmmakers claimed to make "creative documents," one can isolate several constants despite the non-specific and often contradictory nature of the given claims. The authors agree that it is not possible to make an objective film, and it is therefore useless for them to strive for this. In this vein, they also refuse most "objectifying" methods, especially the pursuit of a systematic interpretation or reconstruction of a problem, and instead prefer observational documentary methods. A very common side-effect of this kind of argumentation is an explicit effort to differentiate themselves from investigative journalism typical of television practices. TV documentaries are seen as rigid, formed primarily by the institution of television and its demands in terms of topic, means of depiction, and film length, thereby suppressing authors' creative freedom. On the other hand, the key arbiter in the "creative documentary" is the author (identified with the director), who does not suppress personal values, opinions, sympathies, antipathies and preferences in his or her films. Authors use particular means of expression based on their own personal ideas. If definitions of "creative documentary" consider the viewer, they do so through the subject matter; the viewer is not to be simply supplied with the facts, but should be confronted with the necessity for a critical reappraisal. The supreme authority in the "creative documentary" is therefore "the author", and the measure of "creativity" of his film is its further undefined "peculiarity".

The problem with the concept of the "creative documentary" is thus that it originated at the intersection of professionals and critics associated with the Jihlava festival and Dok.revue, and although it was initially more of a category of self-determination and a creative program, it began to be used also as a theoretical or critical category. Other Czech media unproblematically accepted the concept of the "creative documentary" with all its attributes, i.e. as a category for a priori evaluation ("creative documentary" equals good documentary), which in itself is stripped of any sense in terms of its use in critical discourse. If film critics and professionals share a consensus in their values, this dulls the former's critical edge.

From damnation under the wings (of Czech Television)
Czech documentary filmmaking also appears both radical and tame in its relation to institutions. In the Czech Republic, as in other post-socialist countries, the ambivalent nature of sentiment to the institutional auspices of filmmaking results from domestic documentary filmmakers' separation from their regulator (and, at the same time, employer) after the political upheaval of 1989. The dissolution of the Czechoslovak Film monopoly was followed by the privatization of Short Film (Krátký film), which up until then provided the main resource base for documentary filmmaking. The eager and thoughtless privatization of Short Film, and its placement in the hands of business-based commercial institutions, not only deprived the Czech documentary of production facilities, but also of access to film archives, which were not properly maintained: 
instead of forwarding films to a memory institution (the National Film Archive), this film heritage was passed on to the new owners, who had purely commercial interests. [6] In the early 1990s, the documentary, a relatively unprofitable area of filmmaking, was not a priority for the rapidly developing field of domestic production. Independent producers and distributors focused instead on commercially ambitious feature films, while minority genres (including the animated and documentary film) become dependent on Czech Television, and almost disappeared from cinemas. Czech Television, which was the owner of the rights to the majority of documentary films produced in the 1990s, did not have sufficient capacity or money to support the distribution of its films in the Czech Republic or sales abroad.[7] According to data from the Czech Film Center, only four Czech documentaries reached cinemas (including festival releases) during the whole of the 1990s; in 2000, there were a total of three documentaries in Czech cinemas (see Table 1.)

Table 1. Czech Documentary Films in Cinemas (1990-200o)

\begin{tabular}{|c|c|c|c|}
\hline Title & Director & Year & Production \\
\hline Co dělat & Karel Vachek & 1996 & KF Praha, ČT \\
\hline Zviditelnění & Rodrigo Morales & 1998 & Rodrigo Morales, ČT \\
\hline Černobílá v barvě & Mira Erdevički-Charap & 1999 & ČT, Archimboldo \\
\hline $\begin{array}{l}\text { Zdravý nemocný Vlastimi- } \\
\text { lený Brodský }\end{array}$ & Ondřej Havelka & 1999 & $\begin{array}{l}\text { Whisconti, Fronda Film, ČT, Český } \\
\text { rozhlas }\end{array}$ \\
\hline Bitva o život & Roman Vávra & 2000 & Verbascum, ČT \\
\hline $\begin{array}{l}\text { Bohemia Docta aneb Laby- } \\
\text { rint světa... }\end{array}$ & Karel Vachek & 2000 & KF Praha, ČT \\
\hline $\begin{array}{l}\text { Proroci a básníci. Kapitoly } \\
\text { z kalendáre }\end{array}$ & Ivan Vojnár & 2000 & $\begin{array}{l}\text { ČT, Asociace Film and Sociologie, Gam- } \\
\text { bit film }\end{array}$ \\
\hline
\end{tabular}

A quite telling example of Czech independent documentary production and distribution practices at the beginning of the $2000 \mathrm{~s}$ is provided by the case of Jan Gogola's film Národ sobě aneb České moře $v 18$ prílivech (Nation to Itself, or Czech Sea in 18 Tides, 2001), a semi-documentary film the author called "socially-aesthetic action" with a budget of 10.5 million Czech crowns (five million from the Czech State Fund for the Support of Cinematography, 1.5 million from the producer - Negative, 2.5 million from Barrandov Studios, and 1.5 million from co-producers Universal Production Partners). Despite such

[6] P. Dostál, “Jak je to s privatizací Krátkého filmu?”, Synchron 2003, 2.4, pp. 7-8.

[7] Other important film production companies: Filmová a televizní společnost Febio s.r.o. Fera Feniče, Originální videojournal, $\mathrm{K}_{2}$ Nadace film a sociologie. Even these, however, produced films mostly for CT. The biggest documentary film series produced for TV broadcasting in the 1990s were the following:
Oko (production: Febio s.r.o., rights owner: KF a.s.), GEN (production: Febio s.r.o, rights owner: CT), Dokumentární film pro pamétníky (production: KF a.s., rights owner: KF a.s.), Takoví jsme byli my, dobři rodáci aneb $Z$ letopisů Máselné Lhoty (production: K2, rights owner: CT), Jak se žije (production: Febio s.r.o., rights owner: CT). Source: Institute of Documentary Film. 
support, however, the film did not receive a standard distribution, and during its life-cycle was screened only about 10 times at festivals, and a few times at art cinemas and semi-private screenings.[8]

In such a climate of dependence on CT, efforts began to increase independence, and a gradual reappraisal occurred in the Czech documentary's relation to Czech Television. In the decade after 2001, the year of the first initiative leading towards the establishment of the Institute of Documentary Film, Czech Television functioned as a partner that was always both "near and far" at the same time. Although constantly criticized, it provided documentaries with a stable distribution window and co-production support. However, because of this situation, in the year 2000 the priority of documentary filmmakers became - instead of negotiations and approximation with CT - the search for an alternative means of support: the European audiovisual market. After having gained experience in Europe, the filmmakers would nonetheless later find their way back to CT.

The key activity preceding the establishment of the Institute of Documentary Film was the Pitching Forum (Burza námětů), held from 25 to 28 October 2001, organized under the auspices of The Jihlava International Documentary Film Festival. The authors of the project were two students of the Department of Documentary Film at FAMU in Prague Andrea Prenghyová and Filip Remunda. They formulated their intentions in the minutes of a meeting held on October 2oth 2001, and later published them as an introduction to the manual for the Pitching Forum in 2001. Part of this "manifesto" of the new practice was a special declaration:

We, as students of FAMU, thus beginning directors, have soon learned that it is not easy to shoot a film in the Czech Republic. The dominant producer is Czech Television, which has a limited budget. Many films are shot only due to the strong desire of authors to create, which often overcomes the lack of funds.[9]

What was particularly puzzling about these arguments was the superiority of adequate financial security to the "desire to create", which disregarded the creative act itself as the driving force of the process (which can almost be seen as a denial of the "creative documentary"). The new program latently contained the need to step out of the shadows represented by CT; it protested against the existing models using rhetoric that revealed the unfair and non-transparent decision-making conditions underlying new projects: "The condition is not a name with a high repute, the long-standing position or personal relationships with people from television." Although the act of institutionalizing the IDF reflects a clear tension between young filmmakers and Czech Television and a persistent "trauma" in post-socialist countries seeking a balanced model of state and public support for film production, these sentiments were a rather minor

[8] For more about this project, see P. Lukeš, Na hranicích fikce a sdělitelnosti aneb Národ sobě Jana Gogoly ml., Masarykova univerzita, Brno 2008. Diploma Thesis.
[9] A. Prenghyová, Mezinárodní koprodukce a jejich vliv na podobu současného dokumentu, FAMU, Praha 2005. Diploma Thesis. 
line in the whole project. The Pitching Forum and the consequent steps of its organizers were directed primarily at cultivating domestic production and distribution facilities for documentary filmmaking, and even in retrospect, it is clear that the key contribution of the project was not in the quantitative results achieved, but in "overwriting the field". These two lines - the friendship-hostility relation of Czech documentary filmmakers with CT, and the role of the IDF in the area of Czech documentary filmmaking over the last decade, and the associated transformation of production, distribution and creative practices - are the key axes in the development of the contemporary Czech documentary.

The continuation of the Pitching Forum required stable leadership and a clear profile in terms of the formal and legal aspects. On December 19, 2001, the Ministry of Interior, registered a new civic association the Institute of Documentary Film, a non-profit association focused on the promotion of documentary, independent and creative cinema, and its enforcement on a wider European level. Another goal was to create a functional network consisting of various professional organizations, filmmakers, producers and broadcasters that would provide for exchanges of experiences relating to film production in the framework of international co-productions. Part of the responsibility of the newly formed association was organizing workshops and pitching forums, exhibitions and seminars, which would lead to the promotion of the "creative documentary" and coordination of its production in co-production.[10] Its founder and statutory representatives, Andrea Prenghyová and Filip Remunda, became organizers of the first Pitching Forum.

Table 2. Number of Czech documentary films per year (2001-2008)

\begin{tabular}{llllllll}
\hline 2001 & 2002 & 2003 & 2004 & 2005 & 2006 & 2007 & 2008 \\
\hline 5 & 5 & 3 & 6 & 5 & 10 & 4 & 1 \\
\hline
\end{tabular}

If we follow measurable factors, the curve in the development of the Czech documentary film after 2001 is still very uneven (see Table 2). As the statistics above show, during the IDF's operation the production of documentaries increased significantly in volume only in 2011, when the number of documentaries released exceeded twenty (21) for the first time. The proportion of documentary filmmaking as an aggregate of all audiovisual works produced, however, continues to fluctuate around $5 \%$. IDF has no direct influence on the volume of production; moreover, none of its support programs systematically seeks to increase the number of productions. Key is the development of work and assistance with accessing the viewer. In this respect, in the long term, it is apparent that in terms of total Czech documentary production, a still increasing number of finished films were involved in at least one of the IDF programs, especially the East Silver program, which supports the distribution of

[10] See the Statute of the IDF and its activities: East Silver, Ex Oriente, East European Forum, Docu.
Incubator, Project Czech Document, or East Doc

Platform, <www.dokuweb.cz>. 
documentaries from Central and Eastern Europe.[11] Thanks to cooperation with East Silver in particular, Czech documentaries are also more often distributed and awarded abroad. During the ten years from 2001 to 2011, the role of Czech Television as a co-producer of documentary films shown in cinemas gradually faded. CT was usually involved in half of the documentaries shown in cinemas in a given year. In contrast, however, several independent production companies have continued to significantly strengthen their role and alongside a gradual weakening in the trend of the director-self-producer (Jana Ševčíková, Jan Němec). Despite growing support for international funds, the trend toward international co-productions has not significantly penetrated the Czech documentary environment. Co-productions by Czech filmmakers are still the exception, and are often associated with local themes and cultural specifics.[12]

Even the relatively positive comments of foreign commissioning editors about Czech filmmakers have usually not translated into co-productions. The authors either require that the demands of foreign parties to strictly and schematically match the priorities of their distribution windows and the core of that project, or the foreign editor eventually loses interest. The project Ztracená dovolená (Lost Holiday) by Lucie Králová, for instance, was tripped up by the idea that the film needed a main character, a demand articulated by a commissioning editor, while the director found more productive a layered quest for a group of Asian tourists sparked by photo negatives accidentally discovered ina forgotten trunk, which becomes a quest for identity and memory.[13] Several directors, namely Helena Třeštíková, Martin Mareček, Filip Remunda and Vít Klusák, as well as others, have been able to succeed on the international level with films such as René, Zdroj (Source), Český sen (Czech Dream), and Český mír (Czech Peace) without international coproduction.

The years 2011 and 2012 played a key role in the development of relations between the Czech documentary and Czech Television. Available figures show that in 2011, CT was still a major producer and co-producer of Czech documentary films: its overall financial contribution to the production of Czech non-fiction in general even slightly increased. A more accurate view shows that what rose was above all the amount of money earmarked for CT's own productions, thanks to which the number of documentaries produced also rose from 786 to 950 for the year. Generally, however, CT's participation in co-productions with independent producers has declined, and this has mainly influenced the number of feature-length documentaries. Documentary films that were likely to reach cinemas or be shown at foreign film festivals

[11] The main purpose of East Silver is to promote "creative documentary films" from Central and Eastern Europe and to increase their chances of international distribution, achieved mainly by mediating contacts between leading film professionals and filmmakers and producers. As part of its activities, East Silver provides assistance to producers, working with projects in various stages of development, primarily with completed films as well as films in post-production stage, which are ready to offer for distribution. [12] For more about unsuccessful Czech co-productions, see P. Šafařík, "Česká autorská dokumentaristika a mezinárodní koprodukce”, Do. Revue pro dokumentární film 2007, 5.1, pp. 97-117.

[13] Interview with Lucie Králová, January 2014. 
received significantly less support from CT than in $2010(2,488,000$ CZK of external costs in 2010, 670,000 CZK in 2011; 2,685,000 CZK of internal costs in 2010, 900,000 CZK in 2011).[14]

New leadership at Czech Television, however, was accompanied by a new strategy relating to Czech documentaries and original works in general. Rather than relying on external partners, the CT suddenly adopted something like a "family model". In 2012, CT changed its system for developing programs and program formats, adopting one based on the principle of Creative Producer Groups (CPG).[15] These groups work as a creative project team, whose existence is tied to the development of a specific program. In the original layout, CT had 14 creative producers, some of whom were former independent filmmakers or dramaturges; in 2012 the number grew to 22, of which seven were involved with documentary film:

CFG of social affairs and documentary (Petr Kubica, Martina Šantavá)

CFG of educational film and new formats (Alena Müllerová)

CFG of multi-genre work (Kamila Zlatušková/Brno, Kateřina Ondřejková/Ostrava)

CFG of journalism and documentary filmmaking (Lenka Poláková/Ostrava/)

CFG of alternative journalism and documentary (Antonín Trš) (after the first year of operation this CFG was canceled)

In the first year of the CFGs' operation, 297 projects were approved for production, more than $50 \%$ of which were documentaries.[16]

The curve of distance and convergence of the Czech documentary with Czech Television, which can be easily followed from 2001 to 2012, clearly shows that CT was from a long-term perspective, at times both a rejected and a desired partner. This is a reminder that despite all the advantages related to digitization, new grant opportunities created by European funds, and support activities linked with IDF and Jihlava, as well as the strengthening of the role of independent productions, Czech documentary film still requires a significant partner in television to maintain a healthy state in terms of both production and distribution. In addition to Czech Television, HBO in the Czech Republic has also shown considerable interest in recent years.

The words "Nation to Itself" encapsulate the Czech national legend of a nationwide cash collection thanks to which the National Theatre in Prague was built in 1883 . The slogan located above the proscenium in the

\section{Conclusion}

[14] Press Release IDF (February 2, 2012), online: $<$ http://www.dokweb.net/cs/ceske-dokumenty/fakta-oceskem-dokumentu-cesky-dokument-v-r.-2011-832/?aYear $=2012 \& s a c=64>$ [accessed: February 24th, 2014]. [15] The selection of the chiefs of creative producer groups in Czech TV took place in January 2012, and the names were published on March 14, 2012.
See CT Press Release (March 14, 2012), <http:// www.ceskatelevize.cz/vse-o-ct/press/tiskove-zpravy /?id=6296> [accessed: February 24th, 2014]. [16] See CT Press Release CT (March 6, 2013), <http://www.ceskatelevize.cz/vse-o-ct/press/tiskove-zpravy/?id=6569> [accessed: February 24 th, 2014]. 
finished building was in the subsequent national mythology combined with the image of selfless ordinary people who donated money from their modest income to enable the construction of this temple of national art. It is a poignant story, but unfortunately a false one, as modest gifts could not have built the palatial theater on the river bank. The unquestionable development of the Czech documentary over the last decade has been described through very similar, myth-like stories, stories of small initiatives leading to great things. In descriptions of the establishment of the Jihlava International Documentary Film Festival, the fact that it arose as a student project against the background of the Society of Amateur Filmmakers in Jihlava continues to be emphasized. The Institute of Documentary Film often refers to its origins in the Pitching Forum organized in the fall of 2001 by, once again, FAMU students. The identity of both activities is therefore defined in principle as "student", and associated with the attributes of "studentness" such as independence, creativity, sincere devotion to a (pure) idea, and the like. Such facts about the establishment of both institutions are, of course, not false, but repeatedly emphasizing certain aspects creates a media image of documentary film activities as a priori defensible by the fact that they arose independently or as the result of a struggle, as if created by "the filmmakers for themselves".

Against the background of the stereotypical image of the 1990 s as a restrictive stage for the documentary, it now seems that a phase of demonstrable improvement has arrived, during which the community glorifies any new film, the festival and other activities in this area. In this mythmaking, however, is the core of specific position of Czech documentary in a wider cultural and media discourse. The uncommonness of criticism and rate of polemics responsive to criticisms reveal a fatal problem of Czech documentary film. Its infrastructure (from schooling, film development and production to distribution, exhibition and criticism) is based on an interlinked network of personal relations. Professional standards on all levels are thus formed in quite a close circle, are derived from the notion of "creative documentary" practice and as such also presented in the media This media image outwardly denies a fundamental dependence on institutional support. The rhetoric of independence and individuality conflicts, however, with the efforts to enforce the proponents of "creative documentary" in previously reorganised Czech Television. The fact that the "creative documentary" at the end of its delimitation against the institution of television has found its preserve just under it, is not the result of filmmakers' alienation from their former values. It may serve, however, as a useful insight into the nature of the ambivalent relationship of "independent" art to institutions nowadays.

This work was supported by the project "Employment of Newly Graduated Doctors of Science for Scientific Excellence" (CZ.1.07/2.3.0o/30.00o9) co-financed by the European Social Fund and the state budget of the Czech Republic. 